\title{
COMPARISON OF THE EFFECTS OF NIGELLA SATIVA OIL AND LASER ON TREATMENTS ON EXPERIMENTAL WOUND HEALING IN RATS
}

\author{
RABAB HAJWAL AL-ZAMILY ${ }^{1 *}$, SHROQ MOHAMED ABAS AL-TEMIMI ${ }^{1}$
}

${ }^{1}$ Department of physiology and medical Physics, of Medicine, Al-Qadisiyah University, Al Diwaniyah, Iraq. Email: rabab_alzamily@ yahoo.com Received: 04 April 2019, Revised and Accepted: 30 May 2019

ABSTRACT

Objective:The study investigated the influences of treatment with Nigella sativa oil and laser therapy on wound healing in rats. The period of the inflammatory phase reduced through both laser and N. sativa oil actions; though, the laser was more effective than N. sativa oil, with more significant results.

Methods: We used 52 healthy rats male and divided the rats randomly into three groups. The treatment protocols used included $N$. sativa oil in the first group, laser in the second group, and control in the third group. In all groups, we performed histopathologic evaluations on the $1^{\text {st }}, 3^{\text {rd }}$, $5^{\text {th }}$, and $7^{\text {th }}$ days after surgery.

Results: The proliferation phase of each treatment indicated an increase in the number of fibroblasts, as well as stimulation of collagen formation and synthesis.Positive results on the inflammatory, proliferation, and maturation phases for both treatments of wound healing.

Conclusion:Laser treatment was more effective than N. sativa oil in the first two phases of wound healing.

Keywords:

(C) 2019 The Authors. Published by Innovare Academic Sciences Pvt Ltd. This is an open access article under the CC BY license (http://creativecommons. org/licenses/by/4. 0/) DOI: http://dx.doi.org/10.22159/ajpcr.2019.v12i7.33407

\section{INTRODUCTION}

Several procedures have been applied to investigation healing encouragement; however, little research considered these modalities in compare to each other [1,2]. In this study, we estimated the influence of low-level laser in wound healing and compared it with Nigella sativa oil.

The main objects of the act of damages are fast wound restorative and an able and attractively adequate scar. Interesting growths have meaningfully biologic events complicated in wound restitution. The skin used growth factors to promote wound healing.

Restoration of important reliability and specialty of disturbed tissue of the wound be affected by the interaction of healing stages. These conforming phases comprise inflammation, re-epithelization, granulation tissue formation, wound reduction, and tissue repair. Although fibroblasts confirm an essential in wound healing as well as other elements such as growth factors $[3,4]$.

The usage of ordinary produces as a substitute remedy in wound remedial then remedy has been increasing in the past little periods [5]

Native appliance of black seed oil investigational wounds takes been create to improve wound restorative [6].

Collagen synthesis is essential for wound healing because, during the process, fibroblasts migrate toward the injured area and produce collagen to increase tissue permeability $[7,8]$.

$N$. sativa seed, usually identified as black seed, has been used as an actual medication for several illnesses for hundreds of years in many humanities.

It is most famous for the Prophetic Medicine "Embrace off to application of the Blackseed, aimed at it takes a remedying meant for all disease excepting decease." It includes various dynamic elements comprising thymoquinone, thymohydroquinone, dithymoquinone, thymol, carvacrol, nigellimine, nigellicine, nigellidine, and alpha-hederin.

$N$. sativa seed and its oil were creating to stimulate wound healing in plantation animals [9].

Furthermore, ether extract of $N$. sativa seed applied topically onto staphylococcal-infected skin in mice enhanced healing by reducing total and absolute differential aqueous extricate from $N$. sativa revealed low- slung free radical scavenging action plus encouraged gingival fibroblast propagation by way of hurried wound closing action although its non-significant result on collagen creation [10].

Similar anti-inflammatory effect of $N$. sativa fixed oil and thymoquinone has also been reported earlier by Kirui et al. [11].

Preparations from plants have been used since ancient time to accelerate the process of wound healing. The efficacy of these medicines relies absolutely off on applied practice, then surveillance approved off orally since one generation to the next with little supportive certification.

Wounds are physical damages that caused in disruption of the skin [12].

Wound healing contains an arranged evolution of actions that regenerate the integrity of the injured tissue: Inflammatory, proliferation, and remodeling stages [13].

The dissimilar stages of the wound healing procedure overlay and preferably at least two different courses should be influenced by a plant-based remedying before it is said to have wound healing properties [14].

Several plants in the rough formula or recognized active-components have been examined for their healing effects of skin wounds. 
Conferring to Roy et al. [15] N. sativa is some of the plants that have been extensively applied in local perform to rebuild minor wounds.

The investigation has revealed that the obtain from N. sativa can heal burn-related skin wounds in a rat model [16] and the topical appliance of oil equipped from its seeds can accelerate wound healing $[17,18]$.

Collagen synthesis is essential for wound healing because, during the process, fibroblasts migrate toward the injured area and produce collagen to increase tissue permeability [19]

\section{METHODS}

We used 52 healthy rats male, each $200-250$ g. The study was carried out. Bedding and environmental conditions were similar among all animals. All rats were housed in fed standard rat chow and water was kept in a cleaned mesh cage.

The animals were obtained from the Animals Breeding Center, College of Pharmacy/University of Baghdad. After making a $1 \mathrm{~cm}$ linear incision at the dorsal skin, the locate of incision area in anesthetized animal, we divided the rats randomly into three groups. The treatment protocols used included N. sativa oil in the first group, laser in the second group, and control in the third group five rats were used for primary trials. In all groups, we performed histopathologic evaluations on the $1^{\text {st }}, 3^{\text {rd }}$, $5^{\text {th }}$ and $7^{\text {th }}$ day after surgery.

- Group (1): Consist of (20) animals. The wound incision of animals was the application of the at sativa seed oil daily

- Group (2): Consist of the (20) animals. The wound incision of the animals was exposed to the laser daily

- Group (3): Twelfth animals considered as a control group.

The histopathology inspection was performed to evaluate the amount of inflammatory cells; the microscopic sort's appearance of fibroblast, granulation tissue, and epithelial cells for each sample.

\section{Apparatuses operated}

Helium-neon (He-Ne) laser (China, JGQ-250) continuous of wavelength $632.8 \mathrm{~nm}$ was laboring. Its output power is $0.85 \mathrm{~mW}$ and, a ray point of $0.125 \mathrm{~cm}^{2}$ area at $180 \mathrm{~s}$ and energy density $1.224 \mathrm{~J} / \mathrm{cm}^{2}$.

\section{RESULTS}

The mark of wound healing was observed on the $7^{\text {th }}$ day in the $N$. sativa oil and on the $5^{\text {th }}$ day in the laser treatment group Fig. 1.

The duration of the inflammatory phase decreased in the laser and $N$. sativa oil groups compared with the control groups. Compared with $N$. sativa oil treatment, the laser treatment was found to be more effective, with more significant results.

The proliferation phase was positively affected in the treatment groups by an increase in the number of fibroblasts, as well as stimulation of the collagen synthesis and the composition, compared with the control groups. The laser treatment proved more effective than the N. sativa oil treatment in the proliferation phase. The collagen density and the arrangement were significantly better in the treatment groups than in the control groups, but laser treatment was more effective than N. sativa oil Fig. 2-9.

\section{DISCUSSION}

The topical treatment is widely used as a therapeutic approximate in the handling of wounds $[20,21]$. In wound treatment, topical application is often used as a therapeutic method. Numerous experiments reveal that black seed oil enhances wound healing in the topical appliance [22-25]. Histology analyses approve the enhancement in the wounds remedial of rabbit skin by black seed oil [26-28]. Wound healing includes a flow of actions described by the accomplishment of biological procedures in a definite command and a sure time structure. These actions exemplify the rearrangement of the injured tissue in an effort to repair as normal a disorder as is potential. The normal response of a living organism is to repair the wounds in the shortest time [29].

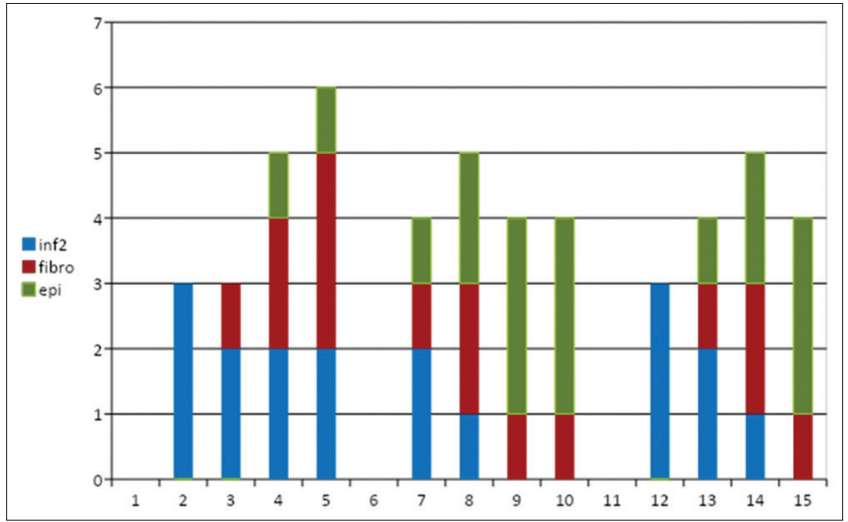

Fig. 1: Wound healing changes after treatment by laser and the local application of Nigella sativa oil with control of the $1^{\text {st }}, 3^{\text {rd }}, 5^{\text {th }}$, and $7^{\text {th }}$ days

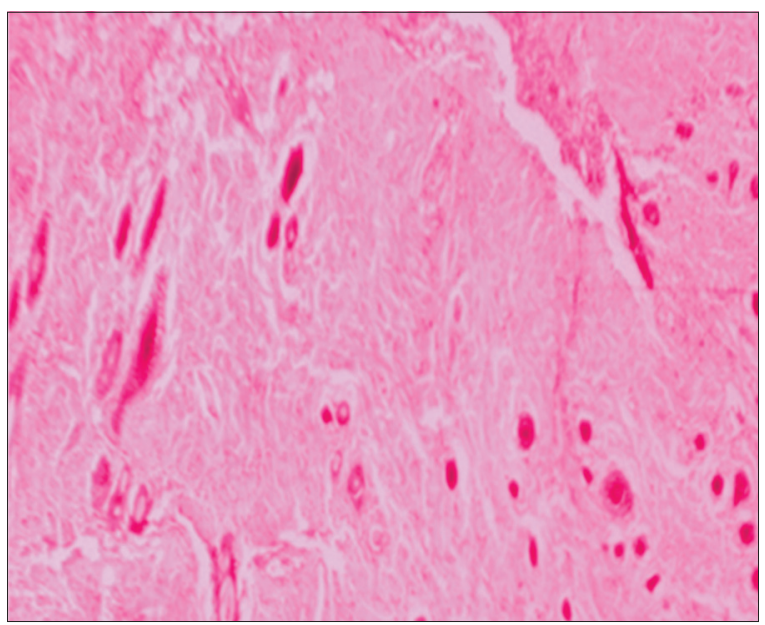

Fig. 2: Three days postoperatively with the application by Nigella sativa oil, show moderate inflammatory cells and mild of fibroblasts plus began the re-epithelization

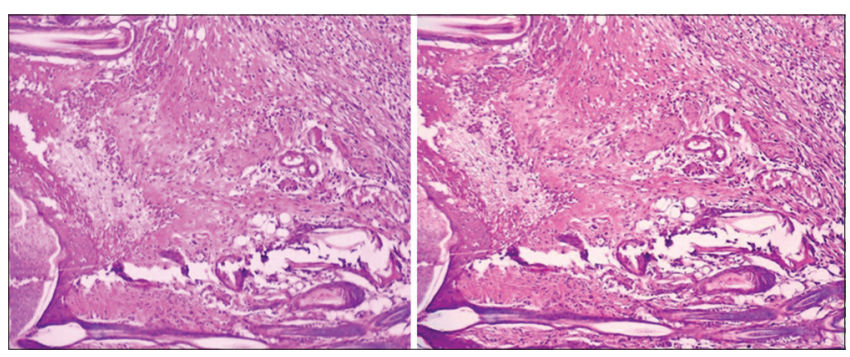

Fig. 3: Three days postoperatively of the control group, there is a moderate amount of inflammatory cells infiltration with mild of fibroblasts and granulation tissue

Prominently of the biological ability of the $N$. sativa seeds exposed toward owed to thymoquinone, the main element off necessary oil. The seeds oil has anti-inflammatory, analgesic, antipyretic, antimicrobial, and antineoplastic action [30-34].

Some researchers who cured hamsters with $N$. sativa oil, and create an important raise of phagocytic action and phagocytic index of peritoneal macrophages and lymphocyte count in the peripheral blood $N$. sativa includes proteins which can accelerate the dermal fibroblast [35].

Laser treatment has also been studied in wound healing [36-40]. 


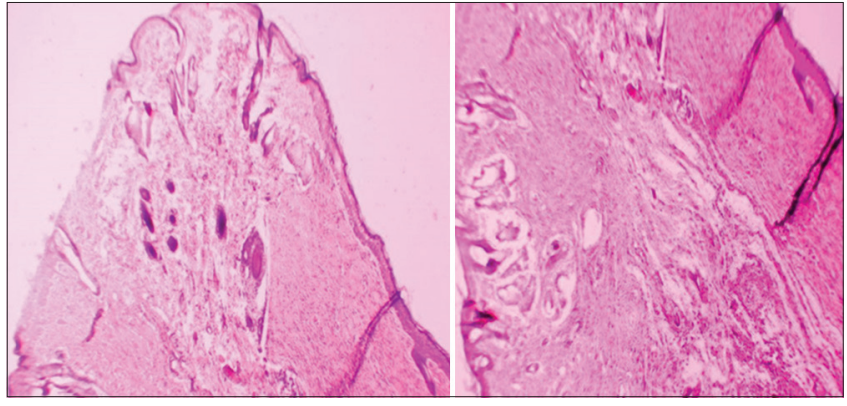

Fig. 4: Healing of irradiated wound by helium-neon laser 3 days postoperatively, moderate of granulation tissue is observed with epithelization

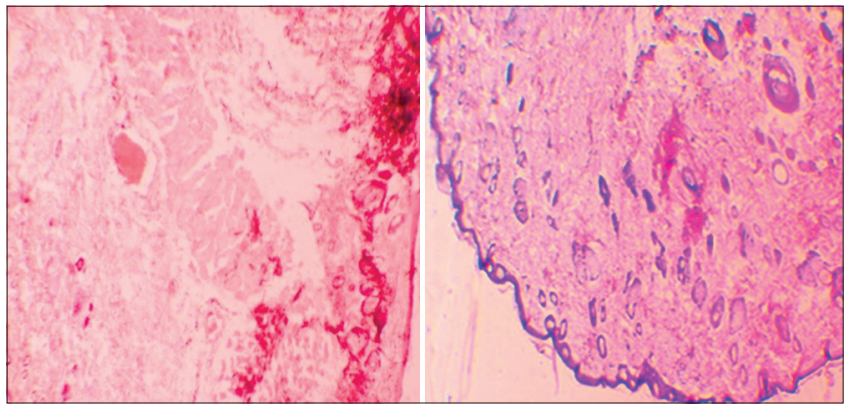

Fig. 5: The 5 days post-operation of the wound by Nigella sativa oil describes by moderate fibroblasts and epithelization plus mild inflammatory cells

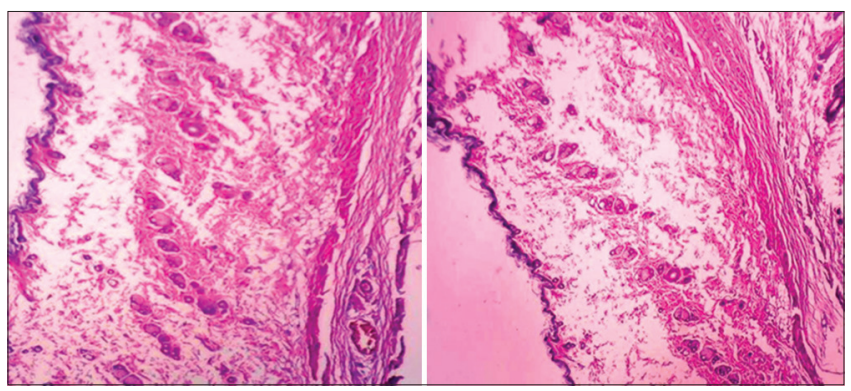

Fig. 6: The line of incision of control group 5 day postoperatively indicates moderate inflammatory cells and fibroblast proliferation. Plus an initial appearance of the epithelization

At present, laser treatment is used for decubitus and diabetic ulcers, open wounds, venous ulcers, graft ulcers, incisions, and burns. Studies in vivo and in vitro showed that laser treatment accelerated biochemical reactions, fibroblast activity, collagen metabolism, neovascularization, qualified scar formation, and wound formation [41-44].

Many researchers proved the success of He-Ne laser in wound healing [45-50].

The amount increased in the laser treatment group compared with its control group. This result shows inhibited inflammation, which is wanted in clean wound healing. Some researchers have reported that low-energy laser treatment decreased the period of the inflammatory phase [51].

When we compared these two modalities in the inflammatory phase, the laser treatment was more effective, with more significant results than the $N$. sativa oil treatment. The numbers of macrophages were decreased in the laser group compared with the $N$. sativa oil group, indicating that the laser treatment decreased the duration of inflammatory phase significantly more than the $N$. sativa oil treatment.

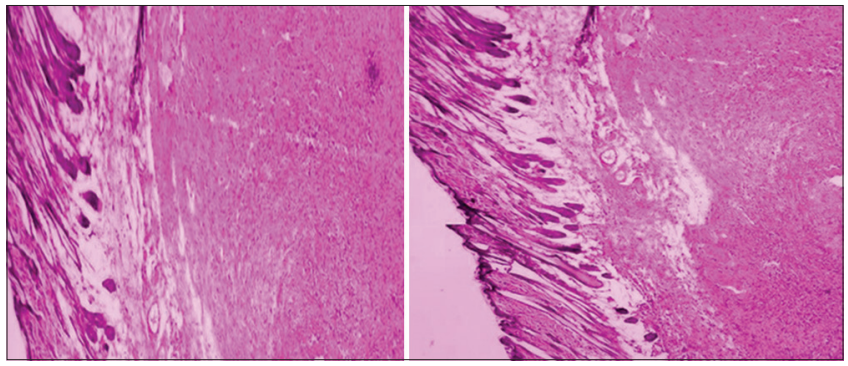

Fig .7: Wound healing irradiated by helium-neon laser is complete 5 days postoperatively which is characterized by epidermis formation at the site of the incision

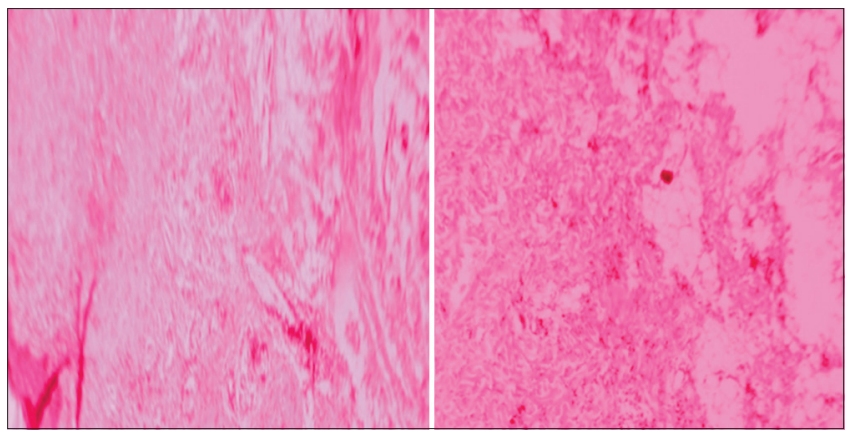

Fig. 8: Wound healing by Nigella sativa oil is complete 7 days postoperatively, cellular fibrous connective tissues are observed

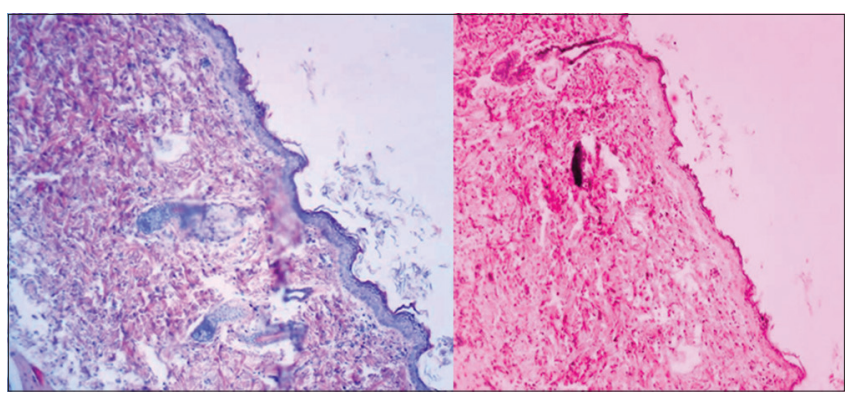

Fig. 9: Line of incision 7 days postoperatively of the control group, show hyperplasia of the epithelial cells with round and thick rete ridge

We could not find any similar study comparing the effect of $N$. sativa oil and laser treatment on wound healing in rats in literature.

In our study, the proliferation phase was positively affected in the treatment groups by the increase in the number of fibroblasts, as well as stimulation of the collagen synthesis and the composition, compared with their control groups. Compared with the N. sativa oil treatment, the laser treatment proved more effective in the proliferation phase.

The maturation or remodeling phase is the last and longest phase of wound healing. The most important development is the remodeling and maturation of collagen during this phase.

Our study showed that both $N$. sativa oil treatment and laser treatment have beneficial effects in the inflammatory, proliferation, and maturation phases of wound healing, compared with their control groups.

However, in tissue sections treated with $N$. sativa oil observed the presence of some of the variables or fiber due to the possibility of the presence of impurities in the commercial N. sativa oil or lack purity or focus accuracy. 


\section{CONCLUSION}

The laser treatment, however, was considered more effective than the N. sativa oil treatment in the first two phases of wound healing.

\section{AUTHOR'S CONTRIBUTIONS}

Prof. Shorouk Mohammed Abbas Al-Tamimi has performed a wide range of reading and analysis of data.

\section{REFERENCES}

1. Salman H, Kashmoola MA, Al-Waiz MM, Al-Sandooq TA. Differences between low level laser therapy and triamcinolone acetonide kenalog on healing of recurrent aphthous ulceration. Ann Coll Med Mosul 2008;34:35-41.

2. Santuzzi CH, Buss HF, Pedrosa DF, Freire MO, Nogueira BV, Gonçalves WL. Combined use of low level laser therapy and cyclooxygenase-2 selective inhibition on skin incisional wound reepithelialization in mice: A preclinical study. An Bras Dermatol 2011;86:278-83.

3. Adzick NS, Lorenz HP. Cells, matrix, growth factors, and the surgeon. The biology of scarless fetal wound repair. Ann Surg 1994;220:10-8.

4. Werner S, Grose R. Regulation of wound healing by growth factors and cytokines. Physiol Rev 2003;83:835-70.

5. Schmidt C, Fronza M, Goettert M, Geller F, Luik S, Flores EM, et al. Biological studies on Brazilian plants used in wound healing. J Ethnopharmacol 2009;122:523-32.

6. Al-Mutheffer EH. The effect of local application of blackseed (Nigella sativa) oil on wound healing in rabbits. Al Anbar J Vet Sci 2010;3:90-7.

7. Barrientos S, Stojadinovic O, Golinko MS, Brem H, Tomic-Canic M. Growth factors and cytokines in wound healing. Wound Repair Regen 2008; 16:585-601.

8. Jorge MP, Madjarof C, Gois Ruiz AL, Fernandes AT, Ferreira Rodrigues RA, de Oliveira Sousa IM, et al. Evaluation of wound healing properties of arrabidaea chica verlot extract. J Ethnopharmacol 2008;118:361-6.

9. Al-Douri AS, Al-Kazaz Sgh A. The effect of Nigella sativa oil (black seed) on the healing of chemically induced oral ulcer in rabbit (experimental study). A1 Rafidain Dent J 2010;10:151-7.

10. Ab Rahman MR, Abdul Razak F, Mohd Bakri M. Evaluation of wound closure activity of Nigella sativa, Melastoma malabathricum, Pluchea indica, and Piper sarmentosum extracts on scratched monolayer of human gingival fibroblasts. Evid Based Complement Alternat Med 2014;2014:190342.

11. Kirui PK, Cameron J, Benghuzzi HA, Tucci M, Patel R, Adah F, et al. Effects of sustained delivery of thymoqiunone on bone healing of male rats. Biomed Sci Instrum 2004:40:111-6.

12. Banks WJ. Applied Veterinary Histology. $3^{\text {rd }}$ ed. Philadelphia: Sydney; 1993.

13. Allen AC. Skin. In: Kissane JM, editor. Anderson's Pathology. $9^{\text {th }}$ ed., Vol. 2. St. Louis: The C.V. Mosby Company; 1990.

14. Houghton PJ, Hylands PJ, Mensah AY, Hensel A, Deters AM. In vitro tests and ethnopharmacological investigations: Wound healing as an example. J Ethnopharmacol 2005;100:100-7.

15. Roy K, Shivakumar H, Sarkar S. Wound healing potential of leaf extracts of Ficus religiosa on wistar albino strain rats. Int J Pharmtech Res 2009;1:506-8.

16. Yaman I, Durmus AS, Ceribasi S, Yaman M. Efects of Nigella sativa and silver sulfadiazine on burn wound healing in rats. Vet Med 2010;55:619-24.

17. Aljabre SH, Alakloby OM, Randhawa MA. Dermatological effects of Nigella sativa. J Dermatol Dermatol Surg 2015;19:92-8.

18. Sari Y, Dhadhang WK, Nasruddin, Saryono, Arington IG, Toshio N. Formulation and evaluation of Nigella sativa oil gel for accelerating diabetic wound healing. Asian J Pharm Biol Res 2014;4:16-22.

19. Probst CW. Wound healing and specific tissue regeneration. In: Slatter D, editor. Text Book of Small Animal Surgery. $2^{\text {nd }}$ ed., Vol. 1. Ch. 4. Philadelphia: W.B. Saunders Company; 1993. p. 53-63.

20. Song JJ, Salcido R. Use of honey in wound care: An update. Adv Skin Wound Care 2011;24:40-4

21. Allwayzy KR. Effect of locally applied black-seed oil and honey mixture on wound healing. Int J Sci Technol Res 2013;2:31-4.

22. Ghedira K. La nigelle cultiv'ée: Nigella sativa L. (Ranunculaceae). Phytothérapie 2006;4:220-6.
23. Awad EM. In vitro decreases of the fibrinolytic potential of cultured human fibrosarcoma cell line, HT1080, by Nigella sativa oil. Phytomedicine 2005;12:100-7.

24. Ait Mbarek L, Ait Mouse H, Elabbadi N, Bensalah M, Gamouh A, Aboufatima R, et al. Anti-tumor properties of blackseed (Nigella sativa L.) extracts. Braz J Med Biol Res 2007;40:839-47.

25. Hosseinzadeh H. Anti-ischemic effect of Nigella sativa L. seed in male rats. Iran J Pharm Res 2006;5:53-8.

26. Abu-Zinadah OA. Using Nigella sativa oil to treat and heal wound of rabbit skin. JKAU Sci 2009;21:335-46.

27. Ostvar O, Shadvar S, Yahaghi E, Azma K, Fayyaz AF, Ahmadi $\mathrm{K}$, et al. Effect of platelet-rich plasma on the healing of cutaneous defects exposed to acute to chronic wounds: A clinico-histopathologic study in rabbits. Diagn Pathol 2015;10:85.

28. Abu-Al-Basal MA. Influence of Nigella sativa fixed oil on some blood parameters and histopathology of skin in staphylococcal-infected BALB/c mice. Pak J Biol Sci 2011;14:1038-46.

29. Nayak S, Nalabothu P, Sandiford S, Bhogadi V, Adogwa A. Evaluation of wound healing activity of Allamanda cathartica. L. and Laurus nobilis. L. extracts on rats. BMC Complement Altern Med 2006;6:12.

30. Priya KS, Arumugam G, Rathinam B, Wells A, Babu M. Celosia argentea linn. Leaf extract improves wound healing in a rat burn wound model. Wound Repair Regen 2004;12:618-25.

31. Ali BH, Blunden G. Pharmacological and toxicological properties of

32. Sigella sativa. Phytother Res 2003;17:299-305. Dhadhang WK, Saryono, Arington IG, Nakatani T. The effect of Nigella sativa oil on wound healing: A pilot study. In: Proceedings of the $1^{\text {st }}$ Borneo Nursing Conference. Pontianak, Indonesia; June,

33. Almin S, Mir SR, Kohli K, Ali B, Ali M. A study of the chemical composition of black cumin oil and its effect on penetration enhancement from transdermal formulations. Nat Prod Res 2010;24:1151-7.

34. Burits M, Bucar F. Antioxidant activity of Nigella sativa essential oil. Phytother Res 2000;14:323-8.

35. Fararh KM, Atoi Y, Shimizu Y, Shiino T, Nikomi H, Takewaki T. Mechanisms of the hypoglycaemic and immuno protectiating effects of Nigella sativa L., oil in streptozotocin induced diabetic hamsters. Res Vet Sci 2004;77:123-9.

36. Hashmi JT, Huang YY, Sharma SK, Kurup DB, De Taboada L, Carroll JD, et al. Effect of pulsing in low-level light therapy. Lasers Surg Med 2010;42:450-66.

37. Chung H, Dai T, Sharma SK, Huang YY, Carroll JD, Hamblin MR. The nuts and bolts of low-level laser (light) therapy. Ann Biomed Eng 2012;40:516-33.

38. Posten W, Wrone DA, Dover JS, Arndt KA, Silapunt S, Alam M. Low-level laser therapy for wound healing: Mechanism and efficacy. Dermatol Surg 2005;31:334-40.

39. Huang YY, Chen AC, Carroll JD, Hamblin MR. Biphasic dose response in low level light therapy. Dose Response 2009;7:358-83.

40. Peplow PV, Chung TY, Ryan B, Baxter GD. Laser photobiomodulation of gene expression and release of growth factors and cytokines from cells in culture: A review of human and animal studies. Photomed Laser Surg 2011;29:285-304.

41. Hashmi JT, Huang YY, Osmani BZ, Sharma SK, Naeser MA, Hamblin MR. Role of low-level laser therapy in neurorehabilitation. PM R 2010;2:S292-305.

42. Hawkins D, Houreld N, Abrahamse H. Low level laser therapy (LLLT) as an effective therapeutic modality for delayed wound healing. Ann N Y Acad Sci 2005;1056:486-93.

43. da Guarda MG, Paraguassú GM, Cerqueira NS, Cury PR, Farias JG, Ramalho LM. Laser gaAlAs $(\lambda 860 \mathrm{~nm})$ photobiomodulation for the treatment of bisphosphonate-induced osteonecrosis of the jaw. Photomed Laser Surg 2012;30:293-7.

44. Bashardoust Tajali S, Macdermid JC, Houghton P, Grewal R. Effects of low power laser irradiation on bone healing in animals: A meta-analysis. J Orthop Surg Res 2010;5:1

45. Hashmi JT, Huang YY, Osmani BZ, Sharma SK, Naeser MA, Hamblin MR. Role of low-level laser therapy in neurorehabilitation. PM R 2010;2:S292-305.

46. Al-Zamily RH. The influence of helium-neon laser irradiation on wound healing. Int J Pharm Bio Sci 2018;9:63-8.

47. Hawkins D, Abrahamse H. Biological effects of helium-neon laser irradiation on normal and wounded human skin fibroblasts. Photomed Laser Surg 2005;23:251-9.

48. Peccin MS, Renno AC, de Oliveira F, Giusti PR, Ribeiro DA. Helium- neon laser improves skin repair in rabbits. J Cosmet Laser Ther 
2012;14:286-9.

49. Liao X, Xie GH, Liu HW, Cheng B, Li SH, Xie S, et al. Helium-neon laser irradiation promotes the proliferation and migration of human epidermal stem cells in vitro: Proposed mechanism for enhanced wound re-epithelialization. Photomed Laser Surg 2014;32:219-25.
50. Al-Zamily RH, Al-Siaidy WF. The effect of helium-neon laser, using different methods and frequencies of radiation, on wound healing. Int J Med Clin Res 2014;5:274.

51. Andrade Fdo S, Clark RM, Ferreira ML. Effects of low-level laser therapy on wound healing. Rev Col Bras Cir 2014;41:129-33. 